\title{
Dictatorship and revolution: Socio-political reconstructions of collective memory in post-authoritarian Portugal ${ }^{1}$
}

\author{
Manuel Loff \\ Universidade do Porto and Instituto de História Contemporânea (Universidade Nova de Lisboa), Faculdade de Letras da Universidade do Porto, \\ Via Panorâmica, s/n, 4150-564 Porto PORTUGAL \\ e-mail: mloff@letras.up.pt
}

Submitted: 15 September 2014. Accepted: 31 October 2014.

\begin{abstract}
This article inserts itself into larger discussions regarding post-dictatorship memory politics in Portugal and comparative studies of similar histories of violence in Europe, particularly examinations of National-Socialism, Nazism and the Holocaust, as well as comparative studies of twentieth-century fascist dictatorships in the Iberian peninsula. In spite of the revolutionary, radical nature of the Portuguese democratisation process, studies conducted during the last four decades on the social and political (re)constructions of memory regarding the Portuguese dictatorship (1926-1974) have demonstrated that state policies regarding the past have depicted the dictatorship as one that is very similar to events in countries where the process of democratic transition was actually quite different from that of Portugal. Right-wing groups and those who self-describe as "victims" of processes of decolonisation that occurred between 1974 and 1975 have established a pattern of public debate that leaves no room for discussing the dictatorship without also referring to the 1974-1975 Revolution. This mode of debate seems to suggest that these two periods of history are indicative of a global regime phenomenon and that both the processes of decolonisation and revolution affected Portuguese society in similar ways. This paper attempts to complicate these narratives in order to question the democratic forms that emerged after the Revolution and to compare it to Salazar's dictatorial regime.
\end{abstract}

KEYWORDS: Collective memory; memorial controversies; Salazar; Estado Novo; 25 April Revolution; revisionism; politics of memory

Citation / Cómo citar este artículo: Loff, Manuel (2014). "Dictatorship and revolution: Socio-political reconstructions of collective memory in post-authoritarian Portugal". Culture \& History Digital Journal, 3(2): e017. doi: http://dx.doi.org/10.3989/ chdj.2014.017

RESUMEN: Dictadura y Revolución: Reconstrucciones sociopolíticas de la memoria colectiva en la Portugal posautoritaria.- Este artículo se encuadra en una discusión más amplia sobre las políticas de la memoria de la posdictadura salazarista en Portugal, y en estudios comparados sobre historias semejantes de violencia en Europa, especialmente las relativas al nacional-socialismo, el nazismo y el Holocausto. También se refiere a los estudios comparados sobre las dictaduras fascistas en la Península Ibérica. A pesar de la naturaleza revolucionaria y radical del proceso de democratización portugués, los estudios llevados a cabo durante las últimas cuatro décadas sobre las (re)construcciones sociales y políticas de la memoria de la dictadura portuguesa (1926-1974) demuestran que las políticas de estado han elaborado un relato de la dictadura en relación con procesos de transición a la democracia que son muy diferentes del portugués. Grupos de extrema derecha y aquéllos que se describen a sí mismos como "víctimas" del proceso de descolonización que tuvo lugar entre 1974 y 1975 han conseguido consolidar en el debate público unos argumentos que no deja espacio para discutir la dictadura sin relacionarla con la revolución de 1974-1975. Los términos de este debate sugieren que estos dos procesos históricos - descolonización y revolución - afectaron a la sociedad de manera semejante. Este texto trata de descifrar la complejidad de estos relatos para poder cuestionar las formas democráticas que emergieron tras la revolución, y compararlas con el régimen dictatorial de Salazar.

PALABRAS CLAVE: Memoria colectiva; controversias sobre memorialización; Salazar; Estado Novo; Revolución del 25 de abril; revisionismo; políticas de la memoria

Copyright: (C) 2014 CSIC This is an open-access article distributed under the terms of the Creative Commons AttributionNon Commercial (by-nc) Spain 3.0 License. 
I think that a crucial part of the interest in a comparative analysis of the Portuguese (and, for that matter, the Spanish) process of coming to terms with a dictatorial past, which began with the democratization of the 1970s, lies mainly in the fact that it occurred while other European societies were confronted with a retour du refoulé, a third and fourth stage (Rousso, 1990) of the post-WWII remembrance of Nazism, Holocaust and collaboration. Clashes in the 1970s and 1980s over attempts to historicize National-Socialism and the Holocaust - the West German 1986 Historikerstreit, although not only that De Felice's critique of the Italian anti-Fascist version of Fascism, controversy over French Holocaust negationism and revisionism, added to the nature of the Vichy regime and genocidal responsibilities were, broadly speaking, contemporary to the Portuguese Revolution (1974-76), Spanish democratic transition (1976-78) and the first stages of the Iberian democracies.

As with the European regimes that resulted from the Nazi and Fascist defeat in 1945, any comparative scheme which brings face to face the Portuguese revolutionary democratization model and others, like the Spanish, in which transition from dictatorship to democracy was based on a (series of) pact(s), should, presumably, find Portuguese public policies of memory of the authoritarian past designed to develop a democratic critique of dictatorship, in a context in which no agreement had been made or even negotiated between representatives of the authoritarian state and opposition movements. But this is not the case in Portugal, and it has almost never been so. To some, it may seem surprising that what emerges from the study of the social and political (re)constructions of the memory of the Portuguese 1926-74 dictatorship in the last four decades is that State policies on the matter drew a very similar picture to those countries in which transition was completely different (see Loff, 2014).

Very soon, as early as the last political clashes of 1975 , a sort of memory screen ${ }^{2}$ was created, especially amongst right-wing groups and those in Portuguese society who describe themselves as victims of decolonization, through which no public debate on the 1926-74 years is allowed without being forced to discuss the 1974-75 Revolution, as if both periods were historically or politically comparable, as if each of them had produced a historical global phenomenon which could legitimately be called a regime, and as if they both had comparable consequences in Portuguese society. For a significant part of society, and quite clearly for all its conservative elements, the Revolution on which democracy had been built had opened the way - or rather coincided with - for a Marxist/Communist/collectivist/totalitarian dictatorship worse than Salazar's. As one of the top-ranking right-wing intellectuals, Vasco Graça Moura, summed it up on the $20^{\text {th }}$ anniversary of the $25^{\text {th }}$ of April 1974, "Revolution did not instate freedom. It overthrew an authoritarian regime but tried to build up a totalitarian regime in its place". 3

It would be very interesting to place such arguments in parallel with those produced in other national cases in which the fall of authoritarian regimes allowed, in some cases for the first time in history, the sort of political and social changes in which the role of Communists and/or other left-wing radical forces was central. Those post-authoritarian transitions of 1944-47 leading, if not to classic liberal-democratic regimes, at least to openly anti-Fascist political systems, were cycles of strong confrontation between those who gained their political legitimacy from resistance to dictatorship and those who represented the old order and their collaborators. Very soon, those who suffered the post-war French épuration or the Italian epurazione pushed forward a representation of the days around 1944 and 1945, as having been as violent and arbitrary as Italian fascism or Vichy and the Occupation (See Cointet, 2008; Woller, 1997; Germinario, 1999), or, indeed, even more so.

In other words, in these narratives, one dictatorship followed another, as in post-war Poland, Czechoslovakia or East Germany, except, perhaps, that the Communists' ban from power in France and Italy had prevented, as they would have it, further sovietization of these countries. The same is said of the sacking and imprisonment of Portuguese left-wing military in November 1975 and the definitive ban on Communists in government in the summer of 1976, after the fall of the last of the pre-constitutional governments in which every major democratic party was represented.

Moving on in time, the complete picture is not as different as one might imagine from, for instance, the postPinochet process of memory reconstruction in Chile in the early 1990s. In this case, the Armed Forces response to the Rettig Report (of the National Committee for Truth and Reconciliation, February 1991) submitted to President Aylwin was to describe its own attitude in the September 1973 coup as a preventive action to "prevent revolutionary civil war in its larval form" (Chilean Army to National Security Council of Chile, quoted in Ensalaco, 2002: 321) - very similar language, in fact, to that Franco always used to explain the July $18^{\text {th }}, 1936$ military uprising against the Spanish Republican democratic government, and, for that matter, the very crux of the neo-Francoist thesis on the responsibilities of Socialists, Communists, Anarchists and Republicans in the 1936-39 Civil War, and thus in all Francoist repression. ${ }^{4}$

In all four cases (France, Italy, Chile, Spain), rightwing memorial discourses (sometimes conveyed through historiography) use concepts like dictatorship and revolution to apply to brief, politically-intense stages, in which strong Communist parties were admitted for a period into large anti-Fascist government coalitions which included different political partners, who shared either a common opposition to a preceding dictatorial Fascist (Mussolini) or fascistized (Pétain) regimes, or to a radical progressive program (Allende's Chile or Republican Spain) which stirred a violent right-wing reaction. In both these cases and in Portugal, in the debate over the memory of a longterm (except in the short-term case of Vichy France) dictatorial experience, discussion is pushed into the political nature of either previous historical experiences (Chilean 
and Spanish cases) against which authoritarians have acted, or the post-authoritarian transitional periods (French, Italian and Portuguese) which allowed societies to overcome dictatorship.

\section{REVOLUTION: AN EMANCIPATED MEMORY OF RESISTANCE, AN AMBIGUOUS MEMORY OF COLONIAL VIOLENCE}

Almost overnight, the April 25 $5^{\text {th }}, 1974$ military coup by the Armed Forces Movement (Movimento das Forças Armadas, MFA) became a revolutionary political break with the past and produced a wide political and institutional elite replacement. Democracy is, in the Portuguese experience of the 1970s, a consequence of both a military coup and social revolution. The transitional process towards a fully institutionalized democracy would last until April 1976, when a new Constitution was passed. Those two years, or rather the 19 months leading up to November 1975, were the Portuguese Revolution. Unlike most other transitions from dictatorship to liberal-democratic regimes, especially all the remaining ones which Samuel Huntington (1991) equivocally assembled in what he called a third wave of democratization, the Portuguese transitional model had all the right conditions to produce a clear rupture with the authoritarian past, politically as well as socially, economically and culturally. Left-wing political culture, in the post-1968 context, was becoming clearly predominant in a society in which industrialization, $\operatorname{war}^{5}$ and massive emigration forced the Portuguese, especially young urban students and workers, to politicize their perception of the world (Loff, 2006).

That clear ideological hegemony of the Left was present in the definition of the Estado Novo, the Portuguese dictatorship of 1926-74, considered a Fascist regime in every legal document passed in the first years of democracy (including the 1976 Constitution). "Fascist repression" was the legal definition of the activity of the political police (PIDE/DGS), and thus of the oppressive nature of Salazarism: "crimes systematically committed against the Portuguese people", "arbitrary and inhumane action", "terrorist activities" and "institutionalized crime". Criminal procedure against those responsible for such crimes became "imprescriptible"6 - a legal principle which remains formally effective, though in fact never evoked.

The military who, together with civilian leaders, ran the country until 1976, paid their own tribute to military victims of the dictatorship: General Humberto Delgado, a Salazarist dissident who became the opposition presidential candidate in 1958, trapped in Spain in 1965 and murdered by the Portuguese political police, was posthumously reintegrated into the Air Force in "public recognition of his virtues and valor"; 7 and every "penalty imposed upon the military in view of the facts that occurred during the invasion of the Portuguese State of India by the Indian armed forces in December 1961" were "nullified". These military did not comply with Salazar's orders to resist à outrance and were punished and ex- pelled from the Army after being released by the Indians and sent back to Portugal. ${ }^{8}$

Social expression of memory of the victims of Salazarist repression was intensely noticeable throughout the revolutionary period (1974-76), marking a first stage in the post-1974 process of remembering a the dictatorship. It was the moment when victims of repression could finally express their grievances, and the moment for those who wanted to listen to and honor them, despite the inevitable political competition between the different organizations and their respective symbolic cultures.

Communist and, to a lesser extent, far-left militants (in the latest stage of the dictatorship) were necessarily recognized to have played an important role, since it was they who had suffered most at the hands of the political police (Polícia Internacional de Defesa do Estado, PIDE, renamed Direção-Geral de Segurança, DGS, in 1969) in Metropolitan Portugal. Edições Sociais, close to the Communist Party (PCP), created a collection specifically dedicated to the Episódios da Resistência Antifascista. Some Socialists and Republicans published their own resistance autobiographical accounts. Most of these memorial recollections had already circulated underground during the 1960s (see Ventura, 2001). A very special place was dedicated to memory accounts of political prisoners (both Communists and Anarchists) who had survived the concentration camp of Tarrafal (1936-54) (see Brito, 2006). In 1978, 32 coffins were transferred from Tarrafal to Lisbon in what became probably the largest public tribute to anti-Fascist resistance members until early this century, when historical Communist leader Álvaro Cunhal's funeral in 2005 brought 250,000 people onto the streets of Lisbon.

Nevertheless, the military origin of the democratization process remains one of the main sources of ambiguity in the social and political elaboration of memory on the Colonial War. In fact, the military remained an inevitable central force in political and social life for some time. In this first stage of post-authoritarian remembrance, an important role was played by the massacres perpetrated by the military in the Colonial War, mostly in Mozambique, while colonial violence as a whole was fundamentally overlooked. In 1975-78, a number of underground publications produced in the last years of dictatorship, especially those prompted by progressive Catholic associations, were republished (Amaro, 1976, 1975a, 1975b, 1978, 1977; Hastings, 1974; Stephan, 1975). Soon after the Revolution and until the early 1990s, State and media overlooked these events. In fact, in 1976, Ramalho Eanes, at that stage the Army's General Chief-of-Staff, shortly before being elected President of the Republic, sued one of the publishers for "abuse of the freedom of the press". 9 Articles on the massacres perpetrated against the populations of Northern Angola (1961) ${ }^{10}$ and Mozambique $(1972)^{11}$ were to be published in 1992-94, making reference to the ex-combatants" "culture of silence", ${ }^{12}$ or to one of the most silenced features of Portuguese warfare, the use of napalm. ${ }^{13}$ But when a TV station picked up some of these stories, the spotlight no longer focused on 
the African survivors but was turned on the Portuguese perpetrators instead. This is true of a 1998 documentary film on the massacre in Wiriyamu and other Mozambican villages (1972) (see Cabrita and Camacho, 1998a), and in the killings perpetrated by nationalists of the União das Populações de Angola (UPA) against Portuguese settlers in Northern Angola (March-April 1961). While, in 1991, reporter Felícia Cabrita had chosen to portray what she called the "days of rage" (reprisal massacres perpetrated by Portuguese settlers in Luanda, in February, and in the Dembos area, from March to June 1961) in the weekly newspaper Expresso, in 1998, another TV documentary displayed no interest in the African victims of the socalled counter-massacres perpetrated by the Portuguese, but only in the settlers who had been victims of the UPA violence (see Cabrita and Camacho, 1998b). A single testimony was collected on the settlers' and military violence, and a final eluding reference is made to it: "In those early Colonial War times, ethical values were often forgotten. (...) Nothing would be the same as before". Nine years later, the tone was clearly different in the widely celebrated documentary A Guerra: Colonial, do Ultramar, de Libertação, produced by the public TV station, and Portuguese war crimes were finally clearly documented (Furtado, 2007).

After forty years of Portuguese democracy, it is still extremely hard to find any reference to Portuguese war crimes in any school history book, or on any education curriculum in any other form. From an official military standpoint, denial has been the rule. The first Portuguese right-wing government after 1974 appointed a Commission for the Study of African Campaigns (1961-1974), ${ }^{14}$ headed by General Themudo Barata, instructing it to "collect systematically and thoroughly all documentation of potential historical and military interest" on the study of "the African Campaigns" (C.E.C.A., 1988: 16), deliberately avoiding the adjective colonial. Its publications would become the most substantial official version of the 1961-74 war prepared by a Portuguese State agency. Their authors were conscious of dealing with the "memory of a significant part of our population", which (according to them) had suffered with "enormous intensity the emotional shock" of that "rare, even unique, metamorphosis in the life of any people": "a country, on its own initiative and conscious of the risk impending over its own survival, being amputated, in a short one-and-half year period, of $95 \%$ of the territory under its sovereignty and for centuries integrated in its vital circuits". For Barata, however, the "national identity crisis" had already "waned" in the 1980s, and "for a large majority of the Portuguese [...] all that may seem now as a pale reminiscence" (C.E.C.A., 1988: 7-8). For this official committee, "overseas territories had always been considered parts of the Portuguese Fatherland", and what they called a "unitarian conviction of Portugal and the Portuguese" was so "compelling to the Portuguese people that its highest representatives, in Government and in Parliament, have never dared, throughout History, to risk [or record] anything that goes against the unity of the Portuguese Nation, per- ceived as pluri-continental, in the fundamental Laws of the Nation (...) [S] uch a conviction existed in the soul of the people and no one would dare to go against it" (C.E.C.A, 1990: 30-31) - an amazing statement by three high-ranking officers ${ }^{15}$ in the Army of a democratic State who had decided, fifteen years earlier, to "dare" to do exactly what they now described as unthinkable.

An openly nationalistic and historically revisionist discourse pervades the five monographic volumes produced by the Commission, which seeks to map out a Portuguese Sonderweg in History, as is usually the case in such discourses. Their core ideas on how to explain the Portuguese presence in Africa, the Colonial War, the fall of the regime and decolonization are fundamentally the same as post-WWII Salazarist literature and propaganda, produced in the context of the assimilationist final stage of Portuguese colonialism, depicting a non-colonialist and non-racist general context in which the "African campaigns" should be read. There was no Colonialism and no colonies but rather "Overseas Provinces" (Províncias Ultramarinas) as, in fact, Salazar called them after the 1951 constitutional reform. There had been no racism but rather a "heterogeneous structure of the Portuguese population, amongst which those living in the African territories have been included [sic] for centuries", and "official Portuguese policy" had "always" been to adapt legislation "to [each colony's] level of development [and] to respect values and culture of every human group and the conviviality tradition among all races". The followers of "Pan-Africanism, by contrast, were racist, becoming Pan-Négritude [...] [, which] carried in itself a racist genus against the white people [and raised it] to a level unknown in the Portuguese territories". The Africans as well as the Portuguese supported the patriotic effort to fight the "terrorists", only by a foreign elite, financed and mobilized by foreign powers, was committed to "expel Portugal straight out of its African territories" (C.E.C.A, 1988: 58, 54, 122). In contrast, not a word was said of the massacres perpetrated by the Portuguese; nor of the 250,000 young dodgers who escaped military service, $20 \%$ of all those called up (see Afonso and Gomes, 2000); or of "the absence of African and mixed people in every important position, both in private and public sector of colonial society, $[\ldots]$ their insignificant representation in the upper level of the educational system [...], the unceasing use of forced labor, expropriation of African land as a pervasive practice, arbitrary arrests and torture and even massacre of entire villages" (Bender, 1980: 11), as established by historical research.

\section{SILENCE, AND POLITICAL AND SOCIAL DEVALUATION OF THE MEMORY OF RESISTANCE}

As is commonplace, social reconstruction of memory followed social and political chronology. A second chronological stage emerged at the end of the Revolution, in what became known (under the hegemonic political discourse produced since then) as democratic normalization. 
After a complex and extremely intense political and social process, which developed between April 1974 and the end of November 1975, those who described themselves as the revolutionary Left (Communists and all movements of the far-Left: Maoists, Trotskyists, Progressive Catholics), including a sizeable part of the military, were ousted from power by an amalgamated coalition of moderate Socialists, all right-wing parties, the Catholic Church hierarchy, and a barely compatible variety of military officers, ranging from moderate left-wing to ultraright Neo-Salazarists, with international support from the USA and Western European governments. After the fall of the last of Vasco Gonçalves' cabinets at the end of August, this coalition prepared an almost bloodless military confrontation with a divided military Left on November $15^{\text {th }}, 1975$, and prevailed.

By then, the Portuguese African colonies had finally been decolonized, during the extremely political hot summer $^{16}$ and autumn of 1975, under complex Cold-War circumstances (South-African invasion of Angola with the help of a significant part of the Portuguese settlers' elite, triggering both Cuban and US intervention), with a huge majority of the Portuguese settlers rejecting the power handover to the African liberation movements. Within a few years, Portugal opened the gates to half a million settlers returning from Africa, plus almost 200,000 emigrants returning mainly from France and Germany, and 100,000 servicemen returning from the colonies where they had been stationed until the formal surrender of power to the new African authorities. Parliamentary elections were held in April 1976, and were won by Soares' Socialists, ${ }^{17}$ and General Ramalho Eanes, one of the military commanders of the November $25^{\text {th }}$ coup, was elected President in July, with the support of a wide coalition including Socialists and the right-wing main parties (PPD and CDS). In December 1979, a right-wing coalition took power and for 16 consecutive years (1979-95), the main right-wing party - Popular Democratic (PPD), renamed Social-Democratic in 1976 - stayed in power, although it was pushed into a grand coalition led by the Socialists in 1983-85. In 1982, a constitutional reform, voted by this same political bloc, put a definite end to the revolutionary cycle, ideologically redesigning the constitutional text and dissolving the last of the Revolution-legitimatized institutional bodies, the Conselho da Revolução, in charge, according to the original text of 1976, of constitutional supervision. Some of its members, especially those who were allies of the Socialist and right-wing forces in the process of defeating the radical Left in the final stage of the Revolution became critical of the Soares' governments (1976-78), the executives appointed directly by President Eanes (1978-79) and the right-wing executives (1979-83) who had emerged in the meantime, and created, in the same year, the Associação 25 de Abril, which made a formal commitment to "collect, preserve and process informative and documentary material related to the History of the $25^{\text {th }}$ of April and the historical process preceding and following it". Paradoxically, in their effort to retrieve "the spirit of the liberating movement of April $25^{\text {th }}, 1974$ " (Art. 3 of the Statute of the Associação 25 de Abril), until the end of the 1980 s, these military, virtually all in the reserve, found only their former opponents of 1975 (Communists and the remains of the far-Left organizations) with whom to celebrate the Revolution.

As literature suggests in a variety of other national cases involving post-authoritarian social expression of memory of oppression, the first two decades subsequent to the revolutionary period - i.e. until the early 1990 s were a period of clear political and social devaluation of those who opposed and resisted the dictatorship, and consequently of their commitment and their memory.

Showing a congenital sense of continuity with an uncomfortable piece of the past (the Salazar era), it is reasonable to say that Portuguese right-wing leaders (but not intellectuals or military of the same political area) preferred, at least until the early years of the $21^{\text {st }}$ century, to remain silent over the dictatorship and the Colonial War which brought the Estado Novo to an end. The whole cultural and social ambiance of the years following the end of the 1974-75 Revolution - recession, decolonization, the rise of a post-industrial society and the structural problems of an economy undergoing a severe process of adaptation following the end of a corporative-controlled economy, and the end of an authoritarian modernization process - allowed economic and political elites (in this case, both Socialist and right-wing) to put almost unanimous blame on the irresponsible hazards of the Revolution for the economic troubles. In fact, as often happens in post-authoritarian societies, memory of recent political confrontation (revolution and decolonization in the Portuguese case) gained precedence over the memory of events that had occurred 15 (Colonial War and massive emigration), 30 (massive disillusionment at the fraud against Delgado in the 1958 presidential election) or 50 years earlier (severe repression in the early years of Salazar's rule). This whole picture gave Portuguese conservatives the opportunity to impose a politically-motivated discussion on the negative legacy of the 19-month Revolution, rather than discussing the 48 years of the Estado Novo, at least whenever it became impossible to elude the debate on Salazar, Caetano, political police, repression, corporatism or war in Africa.

A memory screen had been successfully imposed: no public debate on the 1926-74 years was now possible without a parallel discussion of the 1974-75 Revolution, as if both periods were historically or politically comparable. But were they? By the end of the 1970s, those political forces who had access to power were already avoiding discussion of Salazar, Caetano and their regimes, usually in the name of reconciliation: for Socialists - committed to a moderate discourse, both inside government $(1976-78,1983-85)$ or in opposition to the right-wing administrations (1979-83, 1985-95) - celebrating the Revolution and elaborating on the memory of the dictatorship had become almost too much of a radicalleft approach; for the right-wing parties - to some extent representing second and third generations of families connected with the Estado Novo, and who electorally rep- 
resented conservative social groups who kept and reproduced an essentially positive memory of Salazar and Caetano years - this whole debate was embarrassing and considered uninteresting and unhelpful in the pursuit of economic development. Accordingly, historical legacy of what was an elite consensus over Salazar and over his political paradigm still plays a central role today in the obvious ambiguity shown by Portugal's upper-classes towards the memory of the dictatorship and to their own course of action throughout the last 15 years of the regime. Obvious continuity (family ties, class sociability) of a very significant part of pre- and post-1974 social, economic and cultural elites - in fact, a widespread phenomenon of post-dictatorial societies - is a relevant factor to consider when assessing discourse on the dictatorship years produced in the upper-classes, not only among those who feel close to the ideological nature of the elapsed regime, but more importantly of those who, although hostile to it, tend to exonerate their own relatives or next of kin mostly from their own social class - from the negative core of past experience. It is interesting to see how, a few years ago, after two decades leading the CDS (the more conservative and elitist of Portugal's two major rightwing parties), Diogo Freitas do Amaral, an exceptional case among Portuguese conservative leaders, ${ }^{18}$ complained about the intolerance of the Portuguese rightwing forces regarding the memory of Salazar and his regime, by stating that they seemed to think it "unbearable that someone supposedly right-wing", like himself, should "criticize that regime or that era" in Portuguese history. Amaral said he had "been convinced, but now I think I was wrong, that a huge majority of the Portuguese Right was, or had become, sincerely, a democratic Right". ${ }^{19}$

The 10th anniversary of the Revolution, in 1984, occurred during the worst moment of economic crisis after the fall of the dictatorship. A negative perception of the Revolution and of the democratic system built upon it apparently concealed negative memories of Salazar's regime. In a survey ${ }^{20}$ produced that year, no more than a third of the respondents thought the 25 April Revolution had "improved my personal fulfilment" and around a fifth that it had "improved my economic situation"; only $22.5 \%$ thought the Revolution had been "positive" for "economic development", 24.5\% for "social stability" and $26.4 \%$ for "youth prospects". Ten years later, positive answers to these questions rose to $67.3 \%, 56.2 \%$, $73.6 \%, 65.1 \%$ and $55.3 \%$ respectively. In 1984 , a pervasive negative perception of the revolutionary legacy overlooked all actual data on how democracy had evidently improved mass education: no more than $33.4 \%$ of the respondents thought the revolutionary legacy on "access to education" was good; again, ten years later that figure more than doubled. As is frequently detectable in post-authoritarian societies, social and political liberation was associated with a negative assessment of "public morality" (to $49.7 \%$ of those polled in 1984 , to $45.9 \%$ in 1994) and what was perceived as "crime expansion" $(66.4 \%$ and $76.4 \%)$ and "drug influence [on society]"
(73.4\% and $84 \%)$. In 1984, after decolonization but before integration in the European Community (1986), no more than $35.2 \%$ thought the Revolution had had a "positive effect" on Portuguese "political independence" and only $15.4 \%$ on "economic independence"; by contrast, ten years later, and after eight years of having adhering to the potentially federal project of the EC/EU, positive answers to these questions had increased to $62.7 \%$ and $55 \%$, respectively.

Ten years after the fall of the dictatorship, "freedom" seemed to be the only topic where a relatively positive consensus had been preserved about the revolutionary consensus: $82.5 \%$ of the respondents $(88.4 \%$ in 1994) thought the April 25th uprising had had a "positive effect" regarding "freedom of speech" and 54.8\% (71.8\% in 1994) as far as "youth freedom" was concerned. Apart from these, only "Portugal's image in the world" was positively perceived as the result of the democratic Revolution by half (49.2\%) of the respondents in 1984 (82.2\% in 1994).

In fact, this whole process of apparent collective disappointment with the democratic Revolution, brought about by swiftly decreasing interest in political participation and the pervasive realization of strong structural obstacles to economic development, seem to have produced a relatively coherent new set of values adopted by a solid majority of the Portuguese, mainly reflected in the significant change in political trends which led to two landslide victories (1987 and 1991) for Aníbal Cavaco Silva, the new liberal-conservative leader of PSD and prime minister from 1985 to 1995. A shy authoritarian Economics professor, he posed, like Salazar before him, as an apolitical politician. In the early 1990s, Cavaco felt able to state that July 19"th 1987 (his first landslide) was "the most important date in recent Portuguese history", obviously implying that the April $25^{\text {th }}, 1974$ was not. In 1990, Portugal was included for the first time in the European Value Study created by Ronald Inglehart. This comparative survey showed the Portuguese as being, by far, the most "materialistic" society of any that had been studied: around $40 \%$ of the respondents (doubling European average) tended to subscribe to "materialistic" values such as giving priority to "keeping order in the country" and "fighting inflation" as national "goals for the next ten years", instead of "post-materialistic" values such as "assuring citizens more capacity to participate in important Government decisions" or "defending freedom of expression" (12\%, less than half the European average) (see Freire, 2003).

Furthermore, it may prove significant that some perceived those ten consecutive years (1985-95) in which Portugal was led by Cavaco Silva's administration, known today as the Cavaquismo, as a kind of democratization of Marcelo Caetano's authoritarian modernizing project for Portugal. ${ }^{21}$ It is striking, in this respect, that a significant number of Caetano's collaborators, or those appointed by him to relevant posts in government, returned to political and economic power in the mid-1980s. ${ }^{22}$ 


\section{9-94: REVISIONIST CLIMAX AND THE REBELLION OF ANTIFASCIST MEMORY}

When the Berlin Wall fell and real socialism collapsed in 1989, the attitude of leading right-wing stakeholders (in politics, the media, university and corporations) towards the past was apparently majoritarian: why discuss and research the dictatorship when the Revolution was to blame for what was wrong with Portugal? Thirteen years after the end of revolutionary expectations - or disillusionment - mostly under right-wing governments, social and cultural atmosphere was ripe for the confrontation that occurred between opposing memorial discourses and policies. Social sciences were already producing solid works on most of Salazar's regime dimensions, but that did not, obviously, prevent what may be taken as prototypical revisionist controversy. It then became commonplace to produce memorial accounts on the dictatorship into which were squeezed highly negative references to the Revolution of 1974-76, thus producing a historically-confusing discourse, often clearly anachronistic. Academic mainstream discourse had already evolved from a 1960s and 70s Fascist-categorization of Salazar's Estado Novo (O Fascismo em Portugal, 1982) towards an authoritarian, non-totalitarian and non-Fascist perception (O Estado Novo das origens ao fim da autarcia, 1987; Cruz, 1988), always predominant in AngloSaxon universities, especially in the USA, which had never abandoned the authoritarian classification of the Portuguese benevolent dictatorship. ${ }^{23}$ This was at the core of the first memorial controversies, with neo-Salazarist and liberal-conservative historians and intellectuals, all subscribing to the totalitarian theory precept, denying any similarity between the Estado Novo and Italian and German fascism and reproducing for the Portuguese case De Felice's assumption that definition of Italian fascism until the 1970s would have been imposed by Antifascists. After some theoretical/historiographical essays produced in the 1960s by exiled activists (including Communist leader Álvaro Cunhal's Rumo à Vitória) or scholars who went abroad, not before the late 1980s was there solid historiographical research assessing the fascist characteristic and matrix of Salazar's regime in the 1930s and 40s and rejecting what was by then, a majoritarian authoritarian monochromatic interpretation, disregarding violence, massive repression and mass organizations. ${ }^{24} \mathrm{~A}$ small group among the dictator's inner circle developed a neoSalazarist discourse with some important editorial success. Biographer Franco Nogueira, former minister for Foreign Affairs (1961-69), described the Estado Novo as a "passive State, according to liberal models", as opposed to "a totalitarian State, according to Communist, Fascist or Nazi models". ${ }^{25}$ For two monarchist Law professors in 1989, Salazar's regime was an attempt to "reconcile (...) an authoritarian political practice with formulae inherited from 19th-century liberalism". Only the "vileness, stupidity and dishonesty projected on to the character [Salazar] and his work", together with a "hard silence, orchestrated by today's powerful men and opinion-makers", could ex- plain the "ingratitude" towards Salazar, although they perceived already that it was "starting to be reintegrated in national memory" (Henriques and Melo, 1989: 1011). ${ }^{26}$ In 1991, the Ministry of Education ${ }^{27}$ adopted the authoritarian/benevolent thesis on the Estado Novo, and until the mid-1990s' memorial controversy, silence over the Colonial War and police violence became common practice in most Portuguese elementary and secondary schools (Silva, 2006), while the first postgraduate History program on the dictatorship opened only in 1989 at the Universidade Nova de Lisboa. Until the $25^{\text {th }}$ anniversary of the democratic Revolution, in 1999, both right-wing and center-left governments stuck to the generous Revolution leitmotif, following the strategy adopted by most Western European governments all throughout the Cold War about Nazi occupation and WWII civil wars, assuming an institutional discourse on the need to wipe out bad memories and urging to look to the future and "forget what divided us in the past"... A clear institutional representation of such policies was the fact that until 1996, Cavaco Silva's government hindered legislation which imposed open access to the most relevant archives of the dictatorship: Salazar's personal and political archives, as well as those of the political police (PIDE/DGS). When they were eventually opened to researchers and to everyone who had been persecuted or kept under surveillance, influential sociologist, António Barreto, unsuccessfully proposed their dismantling by suggesting the return of documents on three million people to those affected or their descendants. ${ }^{28}$ The mobilization of historians and other researchers prevented what would have meant the elimination of this vital evidence on the intrinsic nature of the dictatorship.

The year 1989 also marked the $100^{\text {th }}$ anniversary of Salazar's birth, offering one of the few opportunities to seize a fairly official view of Portuguese right-wing political leaders on Salazar and his regime. Freitas do Amaral referred to his "authoritarianism, intolerance, coldness, toughness with his opponents [...], personal seclusion, incapacity for dialogue, mistrust in Portuguese maturity, aversion to individual liberties", but highlighted his "intelligence, culture, $[. .$.$] personal honesty, devotion to public$ interest, willpower, love of Portugal, capacity for government, sense of State, independence from (...) groups of interest, foreign powers", his "ability to conceive a global political project and of executing it step by step". While PM Cavaco Silva avoided any comment at all, one of his ministers, Dias Loureiro, praised Salazar's "expertise" in enabling "Portugal to emerge from [the Spanish Civil War and WWII] paying the lowest cost possible" and the "highly positive" financial policy of the early part of his rule. For Loureiro, as for most right-wingers, it was only "after 1945" that Salazar seemed to have "lost touch with a modern world vision", "placing Portugal outside European recovery dynamics, losing an ideal chance to start industrialization", thus suggesting the fascist years (1930s and WWII) to be Salazar's finest hour. The "Colonial War"- an expression rarely used in right-wing discourses on Salazarism - was harmful to Portuguese society, not so 
much for being an unacceptable deliberate policy of the regime, but because it "further compromised Portuguese [economic] development". Loureiro acknowledged "restrictions imposed on freedom of speech and on freedom of political activity, the absence of a democratic organization of society produced, in fact, economic, cultural and scientific stagnation, delaying [Portuguese accession to] modernity". But, in other words, authoritarianism and dictatorship had not been intrinsically bad as such, but had merely an instrumentally negative impact on economic and cultural "development", and on the process of achieving "modernity". ${ }^{29}$

In contrast, on the left, Socialist leader (and future President of the Republic, 1996-2006) Jorge Sampaio, a student activist in the early 1960s, shared the Left's view that "the Estado Novo was the Portuguese variety, in the specific conditions of Portuguese society and in the context of its genesis (...), of the wave of authoritarian and fascist regimes that swept Europe between the end of WWI and the end of WWII", pointing to the "single party", "corporatism", "censorship", "repression and political police as instruments to coerce Portuguese citizens' thought and action", "manipulation of public opinion through propaganda" as its core characteristics. But Sampaio, like Loureiro, underlined the "productive and technological underdevelopment, dependence on Government protectionism on taxation and from political protest, (...) obsolete industrial and productive organizations", the kind of "obstructions which persist in Portuguese society" that had been "originated and consolidated" by Salazar's policies. For Dias Lourenço, an old-guard Communist resistance member, Salazar "embodied, in Portugal, the answer provided by the most reactionary forces of those years to the unsolvable contradictions and conflicts of the first quarter of the 20th century". His main concern was to point out to "certain 'historians' and 'biographers' who try, under the curtain of Portuguese 'smooth traditions', to elude the inhumane nature of Salazarist Fascism and to prudishly silence death by torture in police dungeons and cold-blooded executions, on the streets, of dozens of patriots, an 'imprisoned country', violent suffocation of freedom and culture", calling on them to "record [these crimes and the violent repression] as Salazar's work". According to Lourenço, by then editor of the Communist weekly Avante, "a significant part of this chapter remains to be written in Portuguese historiography". ${ }^{30}$

The first widespread public debate over the Portuguese dictatorship took place three years later. In April 1992, it became public that the Government was granting pensions to former PIDE inspectors for "exceptional and relevant services rendered to the country", while the same pension had been denied in 1988 to Salgueiro Maia, one of the young captains who led the military operations in April 1974 and who had died a few days earlier (April 4 ${ }^{\text {th }}$, 1992). To add to the controversy, pensions and honors were granted because of "exceptional and relevant deeds on behalf of the Motherland" (Decree No. 404/82, 24.9.1982) during the war in Africa which were appar- ently clearly more relevant than the military operations to overthrow the authoritarian government. Left-wing intellectuals and activists - bringing together, perhaps for the first time, Socialists (starting with President Mário Soares), Communists and small far-Left parties - protested strongly, describing the political culture of the rightwing government as sheer whitewashing ${ }^{31}$ of the dictatorship. This was merely the first stage in a wider and tougher dispute which would reach its apex in 1994, on the Revolution's 20 $0^{\text {th }}$ anniversary. As Luciana Soutelo pointed out, "the legal action of granting [those] pensions to former" torturers, "especially because of the fact that these men had played that role, does not differ significantly from the historical interpretations designed to rehabilitate the Estado Novo and, at the same time, to diminish the meaning and consequences of April 25 $5^{\text {th }}$. (Soutelo, 2009: 263).

A peak in this process was reached in 1994, when a commercial TV station SIC invited one of those political police officers (Óscar Cardoso) to a debate on the dictatorship and the Revolution, together with a historian (José Manuel Tengarrinha) who had been a political prisoner, and a former member of the Conselho da Revolução (Sousa e Castro). Cardoso had been notorious for his actions of extreme violence in Angola and Mozambique during the Colonial War, but SIC's editor Emídio Rangel gave him an opportunity to convey a positively negationistic discourse on the dictatorship political police, focusing on what he presumed had been its main characteristics: "ethics", "patriotism", "scientificity", "effectiveness" or the "gentleness" of its agents. The former inspector, systematically addressed as such by an especially kind moderator, who deliberately avoided embarrassing questions, was impudent enough to deny that torture and executions had been practiced by the political police until 1974. Meanwhile, both the anti-Salazarist resistance member and the MFA military were unable to respond to Cardoso's strategy.

Strong-worded reactions came from anti-Salazarist resistants. For President Mário Soares, "it was as if [Klaus] Barbie - the butcher of Marseille - had been invited to a debate with his own victims". "What are we going to tell our children after they have watched this debate on TV? That we have imagined this whole story? What on earth will be our legacy?" asked editor Torcato Sepúlveda in what was one of the first texts ever published in the press on Portuguese revisionism..$^{33}$ In fact, in the Portuguese debate on the political use of History, concepts such as negationism or revisionism had hardly been used until then; contrast and correlation with other European controversies on $20^{\text {th }}$-century regimes would not be considered of any significance until early in the $21^{\text {st }}$ century (Loff, 1996). On the eve of the $20^{\text {th }}$ anniversary of the Revolution, at last, hundreds of signatories made public a manifesto against the "impudent campaign of whitewashing the previous regime, its agents and its practices, reaching a media peak on the $20^{\text {th }}$ anniversary of the April $25^{\text {th }}$ celebrations. By means of the undervaluation and deliberate mystification of History, and by airing the opin- 
ions, with no adequate critique, of some of its representatives, there is an attempt to cleanse crimes committed by the dictatorship and to retrieve its ideology. [...] And because we do not forget, we also do not consent, through perverting historical reality, to the wiping out of the memory of those who have sacrificed themselves to the fight for democracy". ${ }^{34}$ It was nevertheless quite likely that, among them, were a number of those who, in 197476 , thought it best to "turn the page of past crimes", probably not believing that, at some point, something close to historical "whitewashing" and "mystification" would enjoy such media support.

Very few right-wing intellectuals decided to take part in the 1994 debate. For a short while, but for the first time since 1976, they felt comparatively uneasy. Some, however, went straight to the same old point: if Salazar's dictatorship was bad, the Revolution was worse. Like Vasco Graça Moura. He reacted quite bluntly to those "who decided to recall in the media a whole series of PIDE crimes which is convenient not to forget", but, he stressed, "nobody recalled the arbitrary arrests, censorship, intimidation, tipping off, manipulation, slander, death threats, torture and injuries", as well as - and the mixing up of these is politically quite relevant - "squatting in properties, purges, destruction and other post-April 25th savagery. It was not PIDE who did those. It was the MFA-PCP alliance of rejuvenating memory, that true spittle [sic] on our country's democratization process". ${ }^{35}$

While philosopher José Gil had already argued that the whole debate on political police repression, 20 years after the fall of the regime which had created it, meant that the Portuguese were somehow "[retrieving the] memory of what did not exist (because it was not said, because it happened only as a non-event)", ${ }^{36}$ Moura was sure that "Portugal hasn't yet assimilated its own bad conscience for having been the only country in history" no less -"whose armed forces", as he would have it, "were uniquely fearless in handing over everything they wanted on a plate, without even being defeated". Thus, Moura chose to drag decolonization into the debate, that specific feature of social memory regarding the fall of the authoritarian regime and the Revolution which continued, over the years, to be negatively perceived by a majority of the Portuguese, both until and after 1989. For Moura, the young April captains "preferred, for patriotic reasons, a corporative insubordination of wages and promotions, a preference that was inspired by Soviet motivations and that was almost completely fulfilled. They preferred, heroically, to abandon to their fate [in Angola and Mozambique] millions and millions of people who, in the meantime, died in one of most terrifying catastrophes in the history of mankind and whose responsibility is all theirs". 37

At the same time, a self-portrait was emerging of the Portuguese as the victims of the war: the former combatants, towards whom both society and State had not been as morally appreciative and as legally fair as they felt they were entitled; ${ }^{38}$ the retornados (the Portuguese equivalent to the French pieds noirs), settlers and Afri- cans who chose to return/come to Portugal, self-portrayed as victims of decolonization, of the Revolution, of the liberation movements in Africa, but who hardly felt victims of colonialism and the dictatorship. Self-victimization impelled them to talk about their own experience, openly asking State and society to empathize with their feelings and their pain, as well as their legal demands. The pervading lack of determination of most of the new African States (except perhaps Mozambique) in developing specific memorial policies on the war from an African perspective left room for Portuguese-centered memorial policies conveyed by the Portuguese Armed Forces and former associations of combatants and retornados. ${ }^{39}$

In fact, all those who subscribe to the narrative of the amputated Nation operate inside a widespread consensus on a sort of culturalistic self-indulgent explanation, the Lusotropicalism, committed to proving a special capacity for cultural assimilationism, an alleged multi-racialism and the absence of racial prejudice, a supposedly fatherly attitude of Portuguese colonists. In 2001, José Leitão, first High-Commissioner for Immigration and Ethnic Minorities, under a Socialist administration, forced to respond to reparation demands from some African states and Afro-descendants' organizations in that year's UN Conference against Racism, Racial Discrimination, Xenophobia and Related Forms of Intolerance (Durban), stated that "it is not legitimate to demand official excuses from a country which decolonized, who made itself responsible for its past faults, and which has created a relationship based on solidarity with the Portuguese-speaking African countries". ${ }^{40}$ In fact, Portuguese governments have overlooked, and often denied, the African human tragedy, never investigating or publicizing any figures on the African victims of colonial repression and the 196174 war, do not recognize any war crimes (according to national or international Law: massacres, torture and killing of prisoners, chemical warfare...), and have never discussed any financial reparation with its five former African colonies, India or East-Timor.

\section{THE $21^{\text {st }}$ CENTURY: AN OPEN BATTLE FOR MEMORY}

Meanwhile, in academia, there was a highly significant change in attitude towards historical research on the 1926-74 period. Indeed, research on these subjects have been booming since the late 1990s, as have fiction, autobiography and film (both fictional and documentary). On the one hand, solid works have been produced on Salazarist repression and violence, especially on the role of the political police, and including, at long last, some of its colonial dimensions (see Mateus, 2004; Pimentel, 2007); on the other, as in several other national cases, a kind of nostalgic literature on the two dictators (Salazar, 1928-68, and Marcelo Caetano, 1968-74), both biographical and pseudo-historiographical, as well as on their families and friends, former ministers and so forth, have flooded bookstores and the media, usually written by reporters, but also by certain trendy right-wing histo- 
rians whose work was especially welcomed by publishing houses. A clear symptom of this sort of approach to history and collective memory was the TV contest Grandes Portugueses, broadcast over several months throughout autumn 2006 and winter 2007 by RTP, the public broadcasting company, which imported it from the BBC. RTP had presented it as "good-humored entertainment (...) combining Documentary and Show Business [Grande Espetáculo]. It's a true challenge to the Nation and, at the same time, an excellent moment for a lively debate among the Portuguese on their History". ${ }^{41}$ To give the contest a pedagogical angle, RTP organized a Road-Show to take the debate into several elementary and secondary schools in the country. On the other hand, the TV station decided to appoint a defender (defensor) for the ten characters with most votes in a bizarre first stage to the contest. These included Salazar, defended by far-right researcher Jaime Nogueira Pinto, and Álvaro Cunhal, the former Communist leader, defended by Communist MP Odete Santos. In the last 40 years, it is hard to find a better example addressing the history of the recent past under the extreme conditions imposed by the new media-oriented, technological mass culture, especially with such pedagogical pretensions, which used highly simplistic, virtually acritical procedures, to convey a memorial discourse presented as if it were a collective national memory. After six months, Salazar had won the contest. Filipe Ribeiro de Meneses, author of an acclaimed Political Biography of Salazar, in which he complained about the long-term predominance in "Portuguese historiography" of "Marxist and Annales' models - an obviously overrated assessment of the actual history of History departments in Portuguese universities, even if we only consider the democratic period - accorded the show sufficient relevance and credibility to perceive in "Salazar's victory", a "detectable change of attitude in Portugal towards the recent past" (Meneses, 2009: 12-14).

However, the media became significantly more attentive to scientific research when full access to archives since the mid-1990s began to have an effect. But instead of building a general consensus on these aspects and helping to appease political quarrels over history, archival work which unveiled the repression, corruption and manipulation of Salazar's regime, the authoritarian nature of the postwar modernisation process, produced harsher and more visible clashes between academics: in August 2012, a sort of Portuguese Historikerstreit erupted when I strongly criticized an openly revisionist and negationist essay by monarchist historian Rui Ramos on Portuguese $20^{\text {th }}$-century history when the weekly Expresso decided to include it free for all its readers throughout the summer of 2012, after six consecutive editions of the book had already sold out. ${ }^{42}$ Controversy raged for four months, bringing most $20^{\text {th }}$-century historians, some sociologists and political scientists, into the debate, proving how intense confrontation in this field of action remains. ${ }^{43}$

The open and outspoken battle for memory of the last ten years has helped consolidate the anti-Fascist memory of the dictatorship, but also of the Revolution, in an overt confrontation with the progression of the revisionist discourse of conservative historiography, especially during the decade of Cavaco's right-wing administration. As far as the right-wing memorial policies are concerned, however, what became visible in the $21^{\text {st }}$ century is, more than internal dissonance, a true division of labor: political stakeholder on the right, especially when in government, tend to adopt the same strategy as Spanish post-Francoists, at least until Aznar came to power in 1996: to remain silent on the authoritarian past, to describe collective memory as a matter for family and individual privacy, to approach debates on the matter with apparent lack of interest and indifference, treating them as unhelpful in building the future; on the other hand, the attacks by right-wing intellectuals and academics on the revolutionary heritage of 1974-75 - as well as that of 1910 (the Portuguese Republic) and, to some extent, of the $1820 \mathrm{Lib}-$ eral Revolution - has grown increasingly aggressive, literally importing international revisionism criteria and arguments, retrieving the politics of memory of the 1980s and early 1990s. All in all, revisionist views of the Revolution and the decolonization process still have a strong impact on public opinion, but they have lost the hegemony they seemed to have enjoyed in the mid-1990s, especially because, since the rebellion of memory of 1994 , they have been openly disputed. Consequently, on the two major anniversaries of April 25 $5^{\text {th }}, 1974$ in this new century (the $30^{\text {th }}$ in 2004 and the $40^{\text {th }}$ in 2014), right-wing governments, in power on both occasions, have made an obvious effort to produce a sort of normalized version of the Revolution (as in the 2004 slogan of April is evolution/Abril é evolução), eliminating all its radical significance. Ten years later, at the very recent $40^{\text {th }}$ anniversary, celebrated under the worse social and economic recession since 1984, ruling right-wing parties and neoconservative intellectuals chose to play down (albeit temporarily) their revisionist stance in the face of a widespread revival of revolutionary symbols (songs like Grândola, Vila Morena or Fernando Lopes Graça's and José Gomes Ferreira's resistance Heróicas songs of 1946, the 1970s slogans of the $O$ povo unido jamais será vencido, ...) in rallies and other forms of protest. For quite a number of Portuguese, the 1974 Revolution is apparently still a source of political inspiration, enough to force presidential historical consultant David Justino to ask for "Revolution values to be used to project the future, instead of looking around to find today signs identical to those we lived with before 1974". ${ }^{44}$

A symbolic struggle, however, still continues among different memory discourses disputing hegemony on the process of rebuilding the past. The nature of the visibility of each memory discourse creates a specific balance between the forces operating in this battle over memory. Memorial policies play a central role in the struggle for ideological and symbolical hegemony, in the construction of the terms of perception and organization of social reality: people either remember to preserve or they remember to change. 


\section{NOTES}

1. Manuel Loff is Principal Researcher in the project Estado e memória: políticas públicas da memória da ditadura portuguesa (1974-2009) (PTDC/HIS-HIS/121001/2010).

2. Henry Rousso talks about the French Libération as a "souvenir écran" which pushes backwards the memories of the French 1940 defeat and the German Occupation (Le syndrôme de Vichy...).

3. Moura, Vasco Graça, Diário de Notícias [DN] "Portugal e o passado", 10 April 1994.

4. For the revisionist anti-republican standpoint, Moa (1999) surely remains the most representative example.

5. In February and March 1961, nationalist rebellions in Angola started a Colonial War (1961-74) which soon spread to GuineaBissau (1963) and Mozambique (1964). A total of 920,000 Portuguese soldiers were drafted, 10,000 killed, 30,000 wounded, an estimate of over 100,000 returned from war with Post-Traumatic Stress Disorder

6. Law No. 8/75, 25.7.1975, passed by the Council of the Revolution (Conselho da Revolução, created in March 1975, representing every rank, through delegate election within the Armed Forces). On transitional justice in the years following the Revolution, see Pimentel et al. (2013).

7. Decree No. 647/74, 21 November 1974.

8. Decree No. 727/74, 19 December 1974. The new Provisional Government recognized Indian sovereignty over Goa, Daman and Diu on 31 December 1974.

9. See Expresso-Revista [EV] "A mentira oficial", 5 December 1992.

10. Cabrita, Felícia [EV] "África: os dias da raiva", 16 March 1991: 6-15, including pieces by José Manuel Saraiva and António Costa Santos.

11. Cabrita, Felícia and Azevedo, Clara [EV] "Os mortos não sofrem", 5 December 1992: 12-21.

12. Reis, Patrícia [EV] "Recordações de África", 22 January 1994: 24-31.

13. Carvalho, Frederico [EV] "A guerra do fogo", 26 March 1994: 24-29.

14.. See Portaria No 43/80, 16 February 1980.

15.. This specific volume was written by Generals João I.N. Egreja and Manuel S. Menezes, and Brigadier Orlando R. da Costa.

16.. The expression Verão quente is currently used to describe that period of political and social confrontation.

17. PS: $34.9 \%$ of the votes; PPD: $24.4 \%$; CDS: $16 \%$; PCP: $14.4 \%$; far-Left parties: $4.4 \%$; far-Right parties: $1.1 \%$.

18. Diogo Freitas do Amaral (b. 1941) was one of the youngest members of the dictatorship's second chamber (Câmara Corporativa) in the late years of Marcelo Caetano's rule, and became the founding leader of CDS (Christian-Democrats) in 1974-82 and 1987-91. He was elected President of the UN General Assembly in 1994, and minister for Foreign Affairs in 2005-06.

19. See Notícias Magazine, 9 March 2003.

20. See Visão [Vis] "Sondagem. 25 de Abril? Claro que sim!", 21 April 1994

21. A "democratised Marcelism", an "authoritarian reformism", a "search for an enduring hegemony of power and its identification with the new political class and the nouveau-riches, in a wide populist and clientele-based perspective, supported by the old myth of Portuguese Sebastianist right-wing: the "providential man"" (Franco, 1993: 258). Sebastianism refers to messianic myth on young King Sebastian who disappeared in 1578, at 24, in a disastrous northern Morocco military campaign, retrieved by nationalist intellectuals of the $19^{\text {th }}$ and $20^{\text {th }}$ centuries.

22. See Loff (2009: 79); Castanheira, João Pedro, and Marcelino, Valentina [EV] "Os homens de Marcello: onde estão e o que fazem", 24 April 1993: 22-29.

23. See for the 1970s Graham, 1975; Wheeler, 1983; Schmitter, 1980.

24. See some of the early Fernando Rosas' works (1988, 1989a; 1989b). For an authoritarian non-fascist interpretation of the
Estado Novo, see Manuel Braga da Cruz, João Medina, Hipólito de la Torre, António Telo, António Costa Pinto, Irene Pimentel, Filipe Ribeiro de Meneses, Jacques Georgel, Philippe Schmitter or Yves Léonard; and Neo-salazarists José Hermano Saraiva, Franco Nogueira, Joaquim Veríssimo Serrão or Jaime Nogueira Pinto. For a fascist interpretation, see Loff, Fernando Rosas, Luís Reis Torgal, João Paulo Avelãs Nunes, João Arsénio Nunes, Hermínio Martins, D.L. Raby and the special case of Eduardo Lourenço. Manuel Villaverde Cabral and Manuel de Lucena subscribed to both interpretations on different occasions.

25. See Salazar, 6 vols. (1977-85). Liv. Civilização Editora, Oporto; "II Suplemento”, História de Portugal (1981). Liv. Civilização Editora, Oporto.

26. See also Pinto (1993); Pinto (2007).

27. See Ministério de Educacão, Organização curricular e Programas, vol. I ("Ensino Básico. $3^{\circ}$ Ciclo"), [Lisbon], Reforma Educativa/DGEBS, [1991], p. 139.

28. See Público [PB] "As minhas cartas dos Arquivos da PIDE" 17 April 1996. Former minister in a Socialist government, 197677 , he moved to openly liberal views, has been present in the media ever since and is head of the two major Social Sciences research units (the Instituto de Ciências Sociais) which became a generously-financed neoconservative elitist think-tank.

29. Expresso [Ex] "Como os líderes vêem Salazar", 22 April 1989.

30. Six years later, on the $25^{\text {th }}$ anniversary of Salazar's death, Diário de Noticias asked every "leader of the parties represented in Parliament" to answer three questions on Salazar and on personal memory of his rule, but only the new Socialist (António Guterres) and Communist (Carlos Carvalhas) leaders agreed (see Diário de Notícias [DN], Lisbon, 27 July 1995).

31. Branqueamento is the word commonly used in the Portuguese public debate.

32. Soares, Mário, [PB] "A superioridade moral da democracia [Democracy's moral superiority]”, 22 April 1994

33. Sepúlveda, Torcato, $[P B]$ "A revisão da história", 14 April 1994.

34. "Os abaixo assinados foram presos políticos ou perseguidos políticos durante a ditadura fascista ou são familiares ou amigos de pessoas perseguidas, presas, ou assassinadas por agentes do Estado Novo", manifesto in [PB], Lisbon, 24 April 1994.

35. Moura, Vasco Graça, [DN] "Portugal e o passado", 10 April 1994.

36. Gil, José, [PB] “O silêncio da história”, 9 May 1994.

37. Moura, Vasco Graça, [DN] "Portugal e o passado", 10 April 1994.

38. Former servicemen who suffered from PTSD only saw their right to State indemnities and medical attention legally recognized in 2000, after the approval of Law No. 46/99, under António Guterres' Socialist Administration. See [PB], 23 June 1999 and 13 April 2000. See also Quintais (2000).

39. Half a million fled from the African colonies to Portugal in 1974-76, several hundred thousand chose to remain in Africa, but where the supremacy of white minorities persisted: Ian Smith's Rhodesia and Apartheid South-Africa. For an historiographical appraisal, see Pimenta (2008). For mainstream accounts, see Garcia (2011 and 2012), Marques (2013). In fiction, see Figueiredo (2011) and Magalhaes (2008); or State TV series Depois do Adeus, RTP/SP Televisão, 2012, script by I.Gomes, A.Vasques, C.Dias, J.P.Carneiro, L.Marques, S.Salgado, V.Monteiro, historical consultant neoconservative reporter Helena Matos.

40. [PB], 6 September 2001.

41. «Quem é para si o maior português de sempre?» http://www. rtp.pt/programa/tv/p21257 [accessed July 2014]. The show was co-produced by RTP and D\&D, Portugal, and was presented by reporter Maria Elisa Domingues; Nuno Santos was by then Program Manager.

42. Loff, M., [PB] "Uma história em fascículos” (I and I), and Ramos, Rui, [PB] "Um caso de difamação", 2, 16 and 21 August 2012; Ramos (2009).

43. Controversy involved, to mention only those who published in the press, Maria Filomena Mónica, António Barreto, Vasco Graça Moura, José Manuel Fernandes, Pedro Mexia, João 
Carlos Espada, Bernardo V. e Sousa, Nuno G. Monteiro and Pedro Lomba, all supporting Ramos; Fernando Rosas, João Paulo Avelãs Nunes, José Neves, Ricardo Noronha, Luís Reis Torgal, Dalila Cabrita Mateus, all critising him; and Diogo Ramada Curto, António Guerreiro and Irene Pimentel, criticising both him and me. Filipe Ribeiro de Meneses (whose Salazar. A Political Biography, first published in the USA, was very critical of me in Análise Social, vol. XLVI $\left(2^{\circ}\right)$, Lisbon, 2011 , p. 349-57) describing the controversy in "Slander, Ideological Differences, or Academic Debate? The 'Verão Quente' of 2012 and the State of Portuguese Historiography", in $e$ $J P H$, vol. 10, no. 1, Summer 2012, p. 62-77, in which he chose to explain my attitude as of "slanderous, or quasi-slanderous nature", and, from Dublin where he works, pedantically claimed that, as "rival historiographies at play in today's Portugal (...) find it hard to communicate peacefully with each other, then it is the task of foreign-based academics to mediate between the currents". The right-wing Administration was very clear in taking sides: President Cavaco Silva decorated Ramos on 2013 National Day (June 10 ${ }^{\text {th }}$ ), Prime-Minister Passos Coelho appointed him to the Board of the Luso-American Foundation (see [PB], Lisbon, 18 November 2013) and the Portuguese national agency for scientific and technological research (Fundação para a Ciência e Tecnologia) appointed him to its Social Sciences and Humanities board. On each occasion, controversy was generated in social networks, and among historians and other social scientists.

44. [PB], 6 December 2013.

\section{REFERENCES}

Afonso, Aniceto and Gomes, Carlos Matos (editors), (2000) Guerra Colonial. Editorial Notícias, Lisbon.

Amaro, José (ed. \& comments), (1975a) Boletim Anti-Colonial 1 a 9. Afrontamento, Oporto.

Amaro, José (ed. \& comments), (1975b) Cadernos necessários, 1969-1970. Afrontamento, Oporto.

Amaro, José (ed. \& comments), (1976) Documentos secretos. Massacres na guerra colonial. Tete, um exemplo. Ulmeiro, Lisbon.

Amaro, José (ed. \& comments), (1978) Colonialismo e lutas de libertação. 7 cadernos sobre a guerra colonial. Afrontamento, Oporto.

Amaro, José (ed. \& comments), (1977) Depoimentos de presos políticos. Tortura na colónia de Moçambique, 1963-1974. Afrontamento, Oporto.

Bender, Gerald (1980) Angola sob o domínio português. Mito e realidade, Port. ed., [Originally published as: Angola under the Portuguese. Myth and Reality, Berkeley/Los Angeles, University of California Press, [1976]], Sá da Costa, Lisbon.

Brito, Nélida M.F. (2006) O Tarrafal na memória dos seus prisioneiros, 1936-1954. Foreword by Manuel Loff, Dinossauro, Lisbon.

Cabrita, Felícia and Camacho, Paulo (1998a) Regresso a Wiriyamu. SIC, Lisbon.

Cabrita, Felícia and Camacho, Paulo (1998b) Angola, 1961. O princípio do fim. SIC, Lisbon.

C.E.C.A [Comissão para o Estudo das Campanhas de África] (1988) Resenha histórico-militar das campanhas de África (1961-1974), vol. 1 ("Enquadramento geral"). Estado-Maior do Exército, Lisbon.

C.E.C.A. [Comissão para o Estudo das Campanhas de África] (1990) Subsídios para o estudo da doutrina aplicada nas Campanhas de África (1961-1974). Estado-Maior do Exército, Lisbon.

Cointet, Jean-Paul (2008) Expier Vichy. L'épuration en France, 1943-1958, Perrin, [No city of publication].

Cruz, Manuel Braga da (1988) O Partido e o Estado no Salazarismo. Editorial Presença, Lisbon.

Ensalaco, Mar (2002) Chile bajo Pinochet. La recuperación de la verdad. (Span. EditionAlianza Editorial, Madrid.

Figueiredo, I. (2011) Cadernos de Memórias Coloniais. Angelus Novus, Coimbra.
Furtado, Joaquim (2007) "Massacres contra chacinas". In A Guerra: Colonial, do Ultramar, de Libertação, 3 , RTP, Lisbon.

Franco, António Luciano Sousa (1993) "A economia". In Portugal 20 anos de Democracia edited by Reis, António. [no city of publication]: 170-293

Freire, André (2003) "Pós-materialismo e comportamentos políticos: o caso português em perspectiva comparative". In Atitudes Sociais dos Portugueses, 5 ("Valores sociais: mudanças e contrastes em Portugal e na Europa") edited by Vala, Jorge; Cabral, Manuel Villaverde; Ramos, Alice. Imprensa de Ciências Sociais, Lisbon: 295-361.

Garcia, R., (2011/2012) S.O.S. Angola. Os dias da ponte aérea, and Os que vieram de Africa. Oficina do Livro, Alfragide.

Germinario, Francesco (1999) L'altra memoria. L'Estrema destra. Salò e la Resistenza. Bollati Boringhieri, Turin.

Graham, Lawrence S. (1975) Portugal: the decline and collapse of an authoritarian order. Sage, Beverly Hills.

Graham, Lawrence S. and Wheeler, Douglas L. (editors), (1983) In search of modern Portugal. The revolution and its consequences. Wisconsin University Press.

Hastings, Adrian (1974) Wyryamu. Afrontamento, Oporto.

Henriques, Mendo Castro and Melo, Gonçalo de Sampaio (editors), (1989) Salazar. Pensamento e doutrina política. Textos antológicos. Verbo, Lisboa/S.Paulo.

Huntington, Samuel (1991) Third Wave, Democratisation in the Late 20th Century. Oklahoma University Press, Oklahoma.

Loff, Manuel (1996) "História e memória do Fascismo e da II guerra mundial". In Salazarismo e Franquismo na Época de Hitler (1936-1942). Convergência política, preconceito ideológico e oportunidade histórica na redefinição internacional de Portugal e de Espanha, foreword by Hipólito de la Torre. Campo das Letras, Oporto: 41-93.

Loff, Manuel (2006) "Fim do colonialismo, ruptura política e transformação social em Portugal nos anos setenta”. In Portugal, 30 anos de Democracia (1974-2004), edited by Loff, Manuel and Pereira, Maria da Conceição Meireles. Editora da UP, Oporto: 153-193.

Loff, Manuel (2009) "Coming to Terms with the Dictatorial Past in Portugal after 1974: Silence, Remembrance and Ambiguity”. In Postdiktatorische Geschichtskulturen im Süden und Osten Europas. Bestandsaufnahme und Forschungsperspektiven, edited by Troebst, Stefan and Baumgartl, Susan. Wallstein Verlag, Göttingen: 55-121.

Loff, Manuel (2014, forthcoming) "Estado, democracia e memória: políticas públicas e batalhas pela memória da ditadura portuguesa (1974-2014)". In Ditaduras e Revolução. Democracia e políticas da memória edited by Loff, Manuel; Piedade, Filipe and Soutelo, Luciana Castro. Coimbra: Almedina: 23-143.

Magalhaes, Júlio (2008) Os Retornados. A Esfera dos Livros, Lisbon.

Marques, Alexandra (2013) Segredos da decolonização de Angola. Dom Quixote, Lisbon.

Mateus, Dalila Cabrita, (2004) A PIDE/DGS na Guerra Colonial, 1961-1974. Terramar, Lisbon.

Meneses, Filipe Ribeiro de (2009) Salazar. Uma biografia política, Port. translation, Dom Quixote, Lisbon.

Moa, Pío (1999) Los orígenes de la Guerra Civil. Encuentro, Madrid.

Pimenta, Fernando Tavares (2008) Angola, os Brancos e a Independência. Afrontamento, Oporto.

Pimentel, Irene Flunser (2007) A história da PIDE. Cŕculo de Leitores/Temas\&Debates, Lisbon.

Pimentel, Irene Flunser, and Rezola, Maria Inácia (editors), (2013) Democracia, Ditadura. Memória e Justiça Política. Tinta da China, Lisbon.

Pinto, Jaime Nogueira (editor), (1993) Salazar visto pelos seus próximos (1946-68). Bertrand Editora, Venda Nova.

Pinto, Jaime Nogueira (2007) António de Oliveira Salazar. O outro retrato. A Esfera dos Livros, Lisbon.

Quintais, Luís (2000) As guerras coloniais portuguesas e a invenção da História. ICS, Lisbon.

Ramos, R. (editor), (2007) História de Portugal. A Esfera dos Livros, Lisbon. 
Rousso, Henry (1990) Le syndrôme de Vichy. De 1944 à nos jours. Seuil, Paris.

Rosas, Fernando (1988) "A crise do liberalismo e as origens do 'autoritarismo moderno' e do Estado Novo em Portugal". Penélope. Fazer e desfazer a história, 2, Lisbon.

Rosas, Fernando (1989) "Cinco pontos em torno do estudo comparado do fascismo". Vértice, 13, II Série, Lisbon.

Rosas, Fernando and Brito, José Maria Brandão de (editors), (1989) Salazar e o Salazarismo. Publicações Dom Quixote, Lisbon.

Schmitter, Philippe C. (1980) "The social origins, economic bases and political imperatives of authoritarian rule in Portugal". In Who Were the Fascists, edited by Larsen, S.U.; Hagtvet, B. and Myklebust, J.P. Universitetsforlaget, Bergen/Oslo/Tromsö: 435-466.

Silva, Tiago Matos (2006) "O 25 de Abril tal como é ensinado - a Democracia e o ensino da História". In Portugal, 30 anos de Democracia (1974-2004), edited by Loff, Manuel and Pereira, Maria da Conceição Meireles. Editora da UP, Oporto: 251-63.
Soutelo, Luciana (2009) A memória do 25 de Abril nos anos do cavaquismo: o desenvolvimento do revisionismo histórico através da imprensa (1985-1995), dissertação de Mestrado em História Contemporânea. Faculdade de Letras da Universidade do Porto, Porto.

Stephan, Ernesto (1975) Moçambique, vítima do colonialismo. Prelo Editora, Lisbon.

VV.AA. (1982) O Fascismo em Portugal. Actas do colóquio realizado na Faculdade de Letras de Lisboa em Março de 1980. A Regra do Jogo, Lisbon.

VV.AA. (1987) O Estado Novo das origens ao fim da autarcia, 1926-1959, 2 vols. Fragmentos, Lisbon.

Ventura, António (2001) Memórias da Resistência. Literatura autobiográfica da resistência ao Estado Novo. Câmara Municipal de Lisboa/Biblioteca Museu República e Resistência, Lisbon.

Woller, Hans (1997) I conti con il fascismo. L'epurazione in Italia, 1943-1948. (Ital. Edition) Il Mulino, Bologna. 